DOI https://doi.org/10.18551/rjoas.2018-08.26

\title{
CORPORATE SOCIAL PERFORMANCE, FEMALE DIRECTORS, OWNERSHIP CONCENTRATION AND HUMAN RESOURCE MANAGEMENT PRACTICE
}

\author{
Arini Rizky Mega \\ Economics and Business Department, Airlangga University, Indonesia \\ *Email: rizkymegaarini88@gmail.com
}

\begin{abstract}
The purpose of this study was to test the spirit oversight of female directors, ownership concentration, and human resource practices which gement towards corporate social performance. Corporate social performance measurement with Program Penilaian Peningkatan Kinerja Perusahaan (PROPER). For measurement the percentage of female directors, the percentage of female directors to the directors of directors is used. For the measurement of ownership concentration, the percentage of shares held by the largest shareholder is used. For the measurement of human resource management practices, used indicator of activity which is owned employees in the company, job training received by the employee, the employee welfare support facilities, health facilities for work received by the employee, and work safety facilities received by the employee. The object of research in this study is a public company listed on the Indonesia Stock Exchange period 2014 to 2016 which has PROPER reports and annual reports. The data source in this research idea uses secondary data, company annual report and company PROPER report published by the Ministry of Environment. Data analysis in this study used regression analysis through SPSS. The results of this study indicate that only ownership concentration that has an influence on corporate social performance, while female directors and human resource management practices have no influence on corpoate social performance. The contribution of this research is that companies need to reconsider the composition of share ownership owned by majority shareholders.
\end{abstract}

\section{KEY WORDS}

Corporate social performance, female directors, ownership concentration, human resource management.

Previous studies have tested the many factors thought to influence corporate social performance. Factors thought to have an influence on the corporate social performance include corporate governance, instututional investors, alliance network centrality, firm risk, financial performance, female directors, ownership concentration, human resource management practices and others. We are interested to examine further on the influence of female directors, ownership concentration, and human resource management practices on corporate social performance.

Research by Macaulay, Richard, Peng, and Hasenhuttl (2017) showed that the presence of women on the boards of a positive influence on the social performance of companies. Research conducted by Rothenberg, Hull, \& Tang (2017) showed that human resources practices contribute to the strength of corporate social performance of the company is strong in innovation, and among the companies that enjoy the financial leway. The practice of human resource management is a set of human resource practices to improve employee skills, enhance participation in decision-making, and motivating independent business workers, resulting in the achievement of sustainable competitive advantage of companies (Rothenberg, Hull, \& Tang, 2017). Results of research conducted by Ducassy \& Montandrau (2015) showed that the concentrated ownership has a negative effect on the performance of social, major shareholders are reluctant to spend money on CSR which will benefit all stakeholders. Conversely, holdings scattered improve social performance, which implies a strong CSR commitment by managers, allowing them resolve conflicts with shareholders and other stakeholders. 
We are interested in studying corporate social performance for company as a business organization can not simply aim to maximize profits alone, the company must also pay attention to other aspects such as environmental/social. Indirectly, environmental/social impact of the company's going concern. A company can be shut down by the government because it is considered damaging the environment. Therefore, profit maximization alone can not guarantee the survival of a company.

Corporate social performance (CSP) is defined as the organization's business configuration which is the principle of social responsibility, social responsiveness processes, policy programs, and the results can be observed as it relates to the company's relationship with the community (Hart, David, Shao, Fox, \& Westermann-Behaylo, 2015). CSP generally implies that the company is responsible to stakeholders at large, such as employees, customers, and society (Maas, 2016). Companies with a high CSP will have a higher moral capital which translates into a more favorable ev aluasi for various groups of stakeholders (eg, consumers, employees and investors). In particular, the high moral capital provide such protection for the insurance company's shareholder value by creating goodwill and reduce the negative assessments of their current stakeholder negatively affected in the event of a crisis (Bouslah, Kryzanowski, \& M'Zali, 2016). Corporate social performance is a major aspect of enterprise performance management are poorly researched empirically in the literature to date (Short, McKenny, Ketchen, Snow, \& Hult, 2016).

The object of research in this study is a public company listed on the Indonesia Stock Exchange period 2014 to 2016 which has PROPER reports and annual reports. The sample size is 99 companies. The data source in this research idea uses secondary data, company annual report and company PROPER report published by the Ministry of Environment. Data analysis in this study used regression analysis through SPSS.

The results showed that only ownership concentration which has an influence on corporate social performance, while female directors and human resource management practice has no influence on social corpoate performance. This research contributions is that companies need to reconsider the composition of stock ownership shareholders. Holders of shares is too large (the majority shareholder) has a negative effect to corporate social performance. When the concentration of share ownership by shareholders is too great, this will undermine corporate social performance, and this will impact on the survival of the company. If the Ministry of Environment considers that the management of a company's corporate social performance is too poor and there is no improvement, the Ministry of Environment can make decision to dismiss the company's operating activities, because the operating activities of the company concerned is very damaging to the environment around.

We will discuss the literature review and hypotheses, then the discussion about design research, discussion of the results of research, and then conclusion.

\section{LITERATURE REVIEW}

The role of the board of directors of women who more participatory, more concern on ethics, and more attention to other things, can lead to social performance of companies as a whole is higher in companies with more women on the board of directors (Macaulay, Richard Peng, \& Hasenhuttl, 2017). This means that the more the number of female directors in the board of directors the better the social performance of the company. Results of research conducted by Macaulay, Richard, Peng, and Hasenhuttl (2017) showed that the presence of women on the boards of a positive influence on the social performance of companies. Results of research conducted by Adams \& Funk (2012); Landry et. al (2016); Rao \& Tilt (2016), shows the flood female directors tend to be more sensitive to the social performance of companies. On the basis of this argument, here is the hypothesis constructed:

$\mathrm{H}_{1}$ : The percentage of women directors on the board of directors of the company positively influence on corporate social performance.

Performance corporate social investment has a positive impact on the reputation and prestige, corporate social perforance provides psychological satisfaction for shareholders and top manager, so that shareholders and top manager tends to make a huge investment in 
corporate social performance. This behavior becomes a source of intermediate conflict majority and minority shareholders, as the majority shareholder of the pursuit of personal goals by investing beyond optimal limits and the minority shareholders do not approve this investment if it reduces the value of the company. Search social prestige may harm, published corporate social performance, the majority shareholder increasingly right to pursue an image, not a true altruism (Ducassy \& Montandrau, 2015). This means that the greater the concentration of ownership of the declining social performance of companies. Results of research conducted by Ducassy \& Montandrau (2015) showed that the concentrated ownership has a negative influence on social performance, the majority shareholders are reluctant to spend money on corporate social performance that will benefit all stakeholders. Conversely, holdings scattered improve social performance, which implies a commitment to strong corporate social performance by managers, which allows managers resolve conflicts with shareholders and other stakeholders. The results are consistent with research conducted by Dam \& Scholtens (2013), where the company's social performance decreased with increasing presentation of the largest stock holdings, the sample is a company in Europe. On the basis this argument, here is the hypothesis constructed:

$\mathrm{H}_{2}$ : The concentration of ownership negatively influence on corporate social performance.

Human resource management practices that tend to make social performance into a potentially powerful element of our corporate strategy, while the absence of human resource management practices can reduce or even eliminate social performance quality that makes social performance of companies seen as something weak and unlikely to happen (Rothenberg, Hull, \& Tang, 2017). This means that the higher the human resource management practices are implemented the better the company's corporate social performance. Research result conducted by Rothenberg, Hull, \& Tang (2017) showed that human resources practices contribute to the strength of corporate social performance of the company is strong in innovation, and among the companies that enjoy the financial leeway. The practice of human resource management is a set of human resource practices to improve employee skills, enhance participation in decision-making, and motivating independent business workers, resulting in the achievement of sustainable competitive advantage of companies (Rothenberg, Hull, \& Tang, 2017). Research conducted by Ramus (2001, 2002) and Ramus and Steger (2000) shows that the training focuses on the environment, awards and recognition (human resource management practices) will have a positive effect on the environmental activities such as environmental innovations. On the basis this argument, here is the hypothesis constructed:

$\mathrm{H}_{3}$ : Human resource management practices positively influence on corporate social performance.

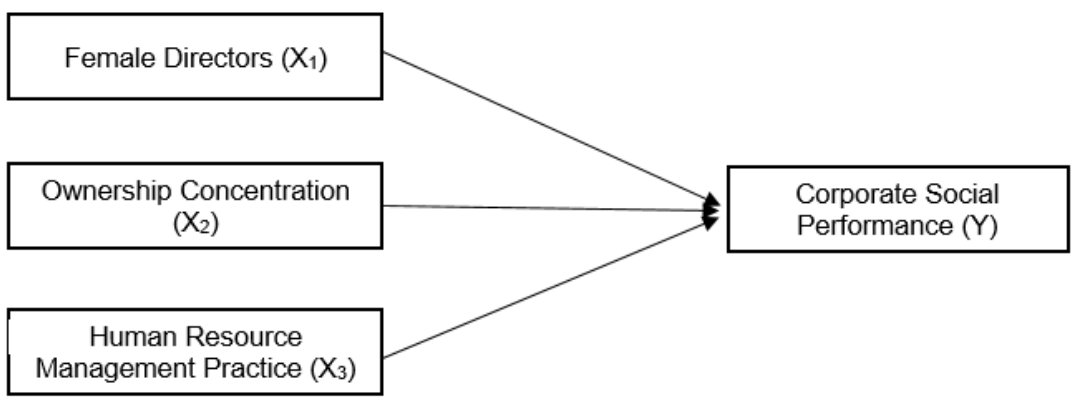

Figure 1 - Conceptual Research Framework

\section{METHODS OF RESEARCH}

This study uses regression analysis to examine the effect of the influence of female directors, ownership concentration, and human resource management practices on corporate social performance. Corporate social performance is the performance of a 
corporate who care about the environment. Corporate social performance proxied by Program Penilaian Peningkatan Kinerja Perusahaan (PROPER), based on research Triwacananingrum \& Hidayat (2014). Extended circles performance rating company is divided into four color ratings: gold, green, blue, and red. The use of color ratings is a form of communication delivery performance to the public to be more easily understood and remembered. Simply put, all four colors will be scored in a row with the highest value, 4 for gold, 3 for green, 2 for blue, and 1 for red.

The concentration of ownership is the largest shareholder ownership. For the measurement of the concentration of ownership, use the percentage of shares held by the largest shareholder, according to a study Ducassy \& Montandrau (2015).

Female directors are women who have positions in the board of directors. Measurement percentage of women directors, used the percentage of women directors to total directors on the board of directors, based on research (Francoeur, Labelle, Balti, and Bouzaidi).

The practice of human resource management is a set of human resource practices implemented by improving employee skills, enhance participation in decision-making, and motivate the self-employed businesses, resulting in the achievement of sustainable and competitive advantage of the company. For the measurement of human resource management practices, used indicator of activity which is owned employees in the company, job training received by the employee, the employee welfare support facilities, health facilities for work received by the employee, and work safety facilities received by the employee. Each indicator gain value of 1 if the company do that and 0 otherwise, based on research Rothenberg, Hull, \& Tang (2017).

The object of research in this study is a public company listed on the Indonesia Stock Exchange period 2014 to 2016 which has PROPER reports and annual reports. The sample size is 99 companies. The data source in this research idea uses secondary data, company annual report and company PROPER report published by the Ministry of Environment. Data analysis in this study used regression analysis through SPSS Test Tools 17.

\section{RESULTS AND DISCUSSION}

Based on the results of the t-test note that the Sig, female directors amounted to 0.231 , this value is greater than $0.05(0.231>0.05)$. This suggests that $\mathrm{H}_{1}$ is rejected, meaning that persentase female directors on the company's board not to positively influence corporate social performance. The results of this study are not consistent with the results of research conducted by Macaulay, Richard, Peng, and Hasenhuttl (2017) which showed that the presence of women on the boards of a positive influence on the social performance of companies. Female Directors on the company's board not to positively influence corporate social performance for composition or presentation of women in boardrooms at companies go public in Indonesia are also willing PROPER program if slightly. Of the 99 samples of the company, there are still many companies that have no female directors on the board of directors and the percentage of women directors in companies with female directors on the board of directors also ranks relatively small percentage compared to male directors. In addition, during the period 2014-2016 in the company sampled, directors' turnover on the board of directors is very little happened, there are only a few companies that experienced a change of directors during the 3-year period. This is what causes women directors does not affect corporate social performanc e in this study.

Sig value. ownership concentration of 0.003 , this value is less than $0.05(0.003<0.05)$. This suggests that $\mathrm{H}_{2}$ is accepted, it means ownership concentration can negatively affect corporate social performance. The results are consistent with the results of research conducted by Ducassy \& Montandrau (2015) which shows that concentrated ownership has a negative effect on social performance. The greater share ownership by the major shareholders, the lower the corporate social performance. Ownership concentration can negatively affect corporate social performance for the majority shareholder does not want to spend some costs in terms of supporting corporate social performance. The majority 
shareholder to think that if they put out a number of costs to support corporate social performance, benefits or rewards gained from expenditure is not profitable for them to the maximum, but instead benefits all stakeholders. Due to feedback received deemed not provide benefits to the Holders of a majority stake, the majority shareholder beinvestasi with a small amount of the corporate social performance. This has led to the growing concentration of ownership will further lower the corporate social performance.

Table 1 - Results of the T-Test

\begin{tabular}{|c|c|c|c|c|c|c|}
\hline \multirow[b]{2}{*}{ Model } & \multicolumn{2}{|c|}{$\begin{array}{l}\text { Unstandardized } \\
\text { Coefficients }\end{array}$} & \multirow{2}{*}{$\begin{array}{l}\text { Standardized } \\
\text { Coefficients } \\
\text { Beta }\end{array}$} & \multirow[t]{2}{*}{$\mathrm{t}$} & \multirow[t]{2}{*}{ Sig. } & \multirow[t]{2}{*}{ Note } \\
\hline & $\mathrm{B}$ & Std. Error & & & & \\
\hline \multirow{4}{*}{$\begin{array}{l}\text { (Constant) } \\
\text { Female Directors } \\
\text { Ownership Conce }\end{array}$} & 1,984 & 0,404 & & 4,906 & 0,000 & \\
\hline & 0,620 & 0,514 & 0,118 & 1,206 & 0,231 & not significant \\
\hline & 0,829 & 0,277 & 0,298 & 2,998 & 0,003 & significant \\
\hline & $-0,469$ & 0,504 & $-0,092$ & $-0,930$ & 0,355 & not significant \\
\hline
\end{tabular}

Dependent Variable: Corporate Social Performance.

Sig value human resource management practice of 0.355 , this value is greater than 0.05 (0.355> 0.05). This shows that $\mathrm{H}_{3}$ is rejected; meaning the practice of human resource management does not positively affect corporate social performance. The results of this study are not in line with the results of research conducted by Rothenberg, Hull, \& Tang (2017) which show that human resource practices contribute to the strength of corporate social performance among companies that are strong in innovation and among companies that enjoy financial slack. Human resource management practices do not positively affect corporate social performance in companies that are sampled because existing human resource management practices are more inclined to improve employee welfare and to improve employee performance in supporting and improving the company's operations. Existing human resource management practices are not specifically implemented to support corporate social performance. In addition, during the period 2014-2016 in the sample companies, the change in human resource management practices held by the company very little happened, there are only a few companies that have changed the practice of human resource management held during the period of 3 years, or can said the practice of human resource management held by companies held by the company tends to be constant during the period 2014-2016. This is why human resource management practices do not affect corporate social performance in this research.

\section{CONCLUSION}

This study was conducted to examine the effect of female directors, ownership concentration, and human resource management practices on corporate social performance. The test results showed that female directors and human resource management practice has no influence on corporate social performance, while ownership concentration has a negative effect on corporate social performance. Female directors have no influence on corporate social performance because the percentage of female directors in the company sampled relatively little. Human resource management practices have no influence on corporate social performance because existing human resource management practices are not specifically conducted to support corporate social performance. While ownership concentration has a negative effect on corporate social performance for beinvestasi majority shareholder with a small amount of the corporate social performance, feedback received is not deemed to provide maximum benefit to the majority shareholder.

The contribution of this research is that companies need to reconsider the composition of share ownership owned by shareholders. Shareholders who have too large shares (majority shareholders) have an adverse influence on corporate social performance. When the concentration of share ownership by shareholders is too great, this will undermine corporate social performance, and this will impact on the survival of the company. If the 
Ministry of Environment believes that corporate social performance management is too bad and there is no improvement, the Ministry of Environment may issue a decision to dismiss the company's operating activities, because the company's operations are very damaging to the surrounding environment.

For future research, to further deepen the ownership composition of concentration, such as seeing family shareholding composition or the composition of foreign shareholdings or the government. Researchers then can further deepen the human resource management practices that encouraged companies that are specifically made for the purpose of supporting corporate social performance.

\section{REFERENCES}

1. Adams, R. B., \& Funk, P. (2012). Beyond the glass ceiling: Does gender matter?. Management science, 58(2), 219-235.

2. Bouslah, K., Kryzanowski, L., \& M'Zali, B. (2016). Social performance and firm risk: impact of the financial crisis. Journal of Business Ethics, 1-27.

3. Dam, L., \& Scholtens, B. (2013). Ownership concentration and CSR policy of European multinational enterprises. Journal of Business Ethics, 118(1), 117-126.

4. Ducassy, I. (2015). Corporate social performance, ownership structure, and corporate governance in France. Research in International Business and Finance, 34, 383-396.

5. Francoeur, C. et al (2017). To What Extent Do Gender Diverse Boards Enhance Corporate Social Performance?. Journal of Business Ethics, 1-15.

6. Hart, T. A., David, P., Shao, F., Fox, C. J., \& Westermann-Behaylo, M. (2015). An examination of the impact of executive compensation disparity on corporate social performance. Strategic Organization, 13(3), 200-223.

7. Ikhsan, Arfan, Muhyarsyah, Hasrudy Tanjung, dan Ayu Oktaviani. (2014). Metodologi Penelitian Bisnis Untuk Akuntansi dan Manajemen. Bandung: Citapustaka Media.

8. Landry, E. E., Bernardi, R. A., \& Bosco, S. M. (2016). Recognition for sustained corporate social responsibility: Female directors make a difference. Corporate Social Responsibility and Environmental Management, 23(1), 27-36.

9. Maas, K. (2016). Do Corporate Social Performance Targets in Executive Compensation Contribute to Corporate Social Performance?. Journal of Business Ethics, 1-13.

10. Macaulay, C., Richard, O., Peng, M., \& Hasenhuttl, M. (2017). Alliance Network Centrality, Board Composition, and Corporate Social Performance. Journal of Business Ethics, 1-12.

11. Ramus, C. A. (2001). Organizational support for employees: Encouraging creative ideas for environmental sustainability. California management review, 43(3), 85-105.

12. Ramus, C. A. (2002). Encouraging innovative environmental actions: What companies and managers must do. Journal of world business, 37(2), 151-164.

13. Ramus, C. A., \& Steger, U. (2000). The roles of supervisory support behaviors and environmental policy in employee "Ecoinitiatives" at leading-edge European companies. Academy of Management journal, 43(4), 605-626.

14. Rao, K., \& Tilt, C. (2016). Board composition and corporate social responsibility: The role of diversity, gender, strategy and decision making. Journal of Business Ethics, 138(2), 327-347.

15. Rothenberg, S., Hull, C. E., \& Tang, Z. (2017). The impact of human resource management on corporate social performance strengths and concerns. Business \& Society, 56(3), 391-418.

16. Short, J. C., McKenny, A. F., Ketchen, D. J., Snow, C. C., \& Hult, G. T. M. (2016). An empirical examination of firm, industry, and temporal effects on corporate social performance. Business \& Society, 55(8), 1122-1156.

17. Triwacananingrum, W., \& Hidayat, W. (2014). Pengaruh Kinerja Sosial dan Financial Leverage terhadap Kinerja Keuangan dengan Klasifikasi Perusahaan sebagai Variabel Moderator Pada BUMN yang Terdaftar Di BEI Periode Tahun 2008-2012. Majalah Ekonomi, 24(2). 